\title{
A Common Beta Tubulin Isotype-1 Gene Single Nucleotide Polymorphism as a Tool for Detection and Quantitation of Anthelmintic Resistant Haemonchus contortus in Grazing Goats
}

\author{
M. M. Corley (Corresponding author) \& A. A. Jarmon \\ P.O. Box 9061 Agriculture Research Station, \\ Virginia State University, Virginia 23806, USA \\ Tel: 804-524-6802-5890 E-mail: mcorley@vsu.edu
}

Received: January 13, $2012 \quad$ Accepted: February 10, $2012 \quad$ Online Published: April 17, 2012
doi:10.5539/jas.v4n6p1
URL: http://dx.doi.org/10.5539/jas.v4n6p1

The authors would like to thank the Virginia State University Animal Care and laboratory staff (Joni Collins, Amanda Miller, Roslyn Stein and Edwina Westbrook). This research was funded by USDA-EVANS ALLEN grant at the Virginia State University Agricultural Research Station Journal Article Series Number 287, Virginia.

\begin{abstract}
Haemonchus contortus, a gastrointestinal parasite costs the global small ruminant industry massive production loss and drug costs per annum. In Haemonchus contortus, one of the single nucleotide polymorphisms (SNP) at codon 200 of the $\beta$ tubulin isotype-1 gene (TTC to TAC), renders this nematode resistant to benzimidazole based anthelmintics. Goats infected with such strains are resistant to benzimidazole based anthelmintics. We used this well established SNP as a diagnostic tool to detect and quantify resistant Haemonchus contortus in grazing goats. Spanish goats had $28 \%$ higher $(\mathrm{P}<0.05)$ amounts of both benzimidazole sensitive and resistant strains of Haemonchus contortus in stool than Myotonic goats. Bucks also had 25\% higher $(\mathrm{P}<0.05)$ of both sensitive and resistant strains than Does. These data demonstrate that this SNP can be used as a diagnostic tool for detection and quantitation of Haemonchus contortus in the stool of grazing goats.
\end{abstract}

Keywords: Haemonchus contortus, Real Time PCR, $\beta$ tubulin isotype-1, Anthelmintic resistance, Goat

\section{Introduction}

Haemonchus contortus is a blood sucking parasite that infects the gastrointestinal tract of small ruminants. Once attached to the abomasal wall the parasite burrows in, mates with other adults and lays eggs that are then passed out through the feces. On contact with the soil, and in favorable conditions, eggs hatch and L3 larvae then attach to the blades of grass in the pasture. Ingestion of these larvae by the animal begins the infection process and the cycle again (Kelly et al., 1978; Silverman \& Campbell, 1959). The small ruminant livestock industry is plagued in part by the parasite Haemonchus contortus because of its resistance to anthelmintic drugs (Barton et al., 1985; Bjørn, Monrad, Kassuku, \& Nansen, 1990; Borgsteede, Pekelder, \& Dercksen, 1996; Howell et al., 2008; Prichard, 1994; Rahman, 1994). Anthelmintics are drugs used to treat gastrointestinal nematodes, but are often misused through frequency of use and lack of definitive diagnosis. As a result Haemonchus contortus becomes resistant to these and therefore infection is becoming difficult to control, and is costly to the industry. Standard diagnostic methods such as FAMACHA eye color reference charts (Ejlertsen, Githigia, Otieno, \& Thamsborg, 2006; Gauly, Schackert, \& Erhardt, 2004; Kaplan et al., 2004; Koopmann, Holst, \& Epe, 2006; Reynecke, van Wyk, Gummow, Dorny, \& Boomker, 2011) (FAM) and packed cell volume (PCV) (Strumia, Sample, \& Hart, 1954; Strumia, Strumia, \& Dugan, 1968) (used to determine clinical anemia), and fecal egg counts (FEC) (Cringoli, Rinaldi, Veneziano, Capelli, \& Scala, 2004; von Samson-Himmelstjerna, Coles, et al., 2009; Várady, Cudeková, \& Corba, 2007) are regularly used to detect Haemonchus contortus infection in goats and in-turn determine whether or not to treat with anthelmintics such as benzimidazoles. Benzimidazoles are a group of anthelmintics used to specifically target the $\beta$ tubulin isotype-1 gene in Haemonchus contortus (Beech, Prichard, \& Scott, 1994; Geary et al., 1992; Lubega, Klein, Geary, \& Prichard, 1994). However, a mutation on the 
$\beta$ tubulin isotype-1 gene of Haemonchus contortus often renders benzimidazoles ineffective (Kwa, Veenstra, \& Roos, 1994; Rufener, Kaminsky, \& Mäser, 2009; Silvestre \& Humbert, 2002). Resistance occurs in Haemonchus contortus because of single nucleotide polymorphisms (SNPs) (Garg \& Yadav, 2009; Ghisi, Kaminsky, \& Mäser, 2007; Kwa, Kooyman, Boersema, \& Roos, 1993; Kwa, Veenstra, \& Roos, 1993; Kwa et al., 1994; Rufener et al., 2009) one of which is in the $\beta$ tubulin -1 gene (TTC (susceptible) to TAC (resistant) (Kwa et al., 1994). Using standard methods alone in determining Haemonchus contortus is insufficient since these methods are both qualitative (FAM) and semi-quantitative (PCV, FEC). Furthermore, clinical anemia and PCV can result from conditions other than Haemonchus contortus infection (Anosa \& Isoun, 1976; Moake \& Schultz, 1975; Nicholson, 2011), and FEC can be inaccurate as it requires counting the parasites by size (Cringoli et al., 2004; Levecke et al., 2011; Rinaldi, Coles, Maurelli, Musella, \& Cringoli, 2011). Therefore it can be unclear as to the causative agent of anemia and whether the drug will work. The need for evaluation of genomic diagnostic tools has resulted in studies attempting to develop definitive diagnostic methods for Haemonchus contortus infection in small ruminants (Alvarez-Sánchez, Pérez-García, Cruz-Rojo, \& Rojo-Vázquez, 2005; Gilleard, 2006; Höglund et al., 2009; Otsen et al., 2001; Otsen, Plas, Lenstra, Roos, \& Hoekstra, 2000; Silvestre \& Humbert, 2000; Tiwari et al., 2006; von Samson-Himmelstjerna, Walsh, et al., 2009). We therefore demonstrate use of the well established SNP of the $\beta$ tubulin isotype-1 gene as a dual molecular based diagnostic tool for quantitation (both semi-quantitative and quantitative) of Haemonchus contortus load and detection of its resistance to benzimidazole based anthelmintics in grazing goats.

\section{Materials and Methods}

\subsection{Animals and Standard Method Detection}

Spanish and myotonic goats housed at VSU Randolph farm and grazing pasture were screened for parasite load via FEC using a modification of the McMaster technique (Cringoli et al., 2004). In brief, fresh rectal fecal samples were collected into sterile bags and stored at $-80^{\circ} \mathrm{C}$ for molecular analysis. Strongyle/Trichostrongyle eggs (80-90 microns) were counted at a 10X microscopic magnification and eggs per gram EPG (total eggs X 50) determined. Blood samples were collected and analyzed for PCV via the micro-hematocrit method (Strumia et al., 1954). Clinical anemia status was determined using FAMACHA eye color chart scores $(\leq 3=$ normal, 4 or $5=$ anemia). The EPG, FAM and PCV data collected were analyzed using SAS version 9.1.3, (Cary, North Carolina).

\subsection{Total RNA Extraction of Haemonchus Contortus from Goat Feces}

Total RNA was isolated from goat fecal samples previously stored at $-80^{\circ} \mathrm{C}$ using a modified (Gauthier, Madison, \& Michel, 1997) RNA isolation procedure. Approximately $220 \mathrm{mg}$ of frozen feces was weighed out and placed into sterile $5 \mathrm{ml}$ eppendorf centrifuge tubes. Under a fume hood, $1 \mathrm{ml}$ of Guanidine thiocyanate (GTC) (4M GTC, $25 \mathrm{mM}$ Sodium citrate $\mathrm{pH} 7.0$ and $\mathrm{N}-0.5 \%$ lauroylsarcosine) was added to each tube along with $0.1 \mathrm{M}$ 2-mercaptoethanol ( 0.01 of total volume) and homogenized. Subsequently, one-tenth of the total volume of $2 \mathrm{M}$ sodium acetate was added to each tube and vortexed. One volume of phenol:chloroform:isoamyl alchohol $(25: 24: 1)$ was then added to each tube and the tube placed on ice for 15 minutes. The tubes were then centrifuged at $5000 \mathrm{rpm}$ for 20 minutes in a refrigerated centrifuge (Megafuge $16 \mathrm{R}$, Thermoscientific). The Phenol extraction step was repeated twice in order to maximize purity of extracted RNA. The remaining steps in the extraction followed the referenced procedure (Gauthier et al., 1997) except for the centrifugations steps described above and DNase treatment $(1 \mathrm{U} / \mu \mathrm{l})$ to remove contaminating genomic DNA. Concentration and purity of total RNA was determined using a Nanodrop ND-1000 spectrophotometer (Thermoscientific). The RNA was stored at $-80^{\circ} \mathrm{C}$ for later use in RT-PCR and quantitative Real Time PCR (qRT-PCR).

\subsection{Reverse Transcriptase PCR (RT-PCR)}

Oligonucleotide primers were designed from mRNA of the Haemonchus contortus $\beta$ tubulin isotype-1 gene (GenBank Accession GQ910909) to target the SNP (TTC to TAC) using the primer design feature of the bioinformatics software, CLC Main Workbench (http://www.clcbio.com). Primers and target regions used for initial detection and amplification of the SNP are given in Table 1. For amplication of the sensitive and resistant alleles the designated primers and the GOReverse were used as primer pairs. The RT-PCR was conducted using the recommended protocol of the Verso 1-step RT-PCR kit (ThermoScientific) except $1 \mu \mathrm{l}$ of BSA (50mg/ml) was added to each reaction to counteract remaining fecal contaminating proteins. Thermocyling conditions for 40 cycles were as follows: $50^{\circ} \mathrm{C} 15$ minutes, $95^{\circ} \mathrm{C}, 2$ minutes (initial denaturation), $95^{\circ} \mathrm{C}, 30$ secs, $55^{\circ} \mathrm{C}, 1$ minute, $72^{\circ} \mathrm{C}, 1$ minute repeated 39 times and a final extension at $72^{\circ} \mathrm{C}$ for 5 minutes. Successful amplification of the target Haemonchus contortus $\beta$ tubulin isotype- 1 cDNA was verified by $1.5 \%$ agarose gel electrophoresis and visualized using a U:Genius UV gel documentation system (SynGene, Fredericksburg, MD) equipped with a high resolution CCD camera for quality image capture and configured with Genetools Analysis Software. 


\subsection{Gene Sequence Verification}

For $\beta$ tubulin isotype-1 and SNP verification, the amplified RT-PCR products were purified from gels (Freeze N Squeeze, Bio-Rad) and PCR clean up columns (Qiagen and Bio-Rad) and sequenced at GeneWiz (South Plainfield, New Jersey). Nucleotide sequences were analyzed using sequence analysis software (NCBI-BLAST, CLC Main Workbench). Following gene verification, qRT-PCR and endpoint PCR (Genetools UV gel documentation software) analysis (semiquantitative) were conducted to detect and quantify benzimidazole resistant and sensitive strains of Haemonchus contortus.

\subsection{Quantitative Real Time-RT-PCR}

Quantitative Real Time RT-PCR was conducted using the iScript One Step RT-PCR kit with SYBR Green (BioRad). In a $50 \mu \mathrm{l}$ reaction, forward primers $(300 \mathrm{nM}$ each) targeting sensitive and resistant alleles were prepared in separate reactions each with a common reverse primer. DNase treated total RNA (100ng) was added to each reaction. The $\beta$-Actin gene was used as an internal standard for relative quantity calculation. Thermal cycling conditions were performed as recommended. Briefly, thermal cycling conditions entailed cDNA synthesis: $10 \mathrm{~min}$ at $50^{\circ} \mathrm{C}$, iScript Reverse transcriptase inactivation: $5 \mathrm{~min}$ at $95^{\circ} \mathrm{C}$. PCR cycling and detection ( 45 cycles): 10 to $15 \mathrm{sec}$ at $95^{\circ} \mathrm{C} 30 \mathrm{sec}$ at $55^{\circ} \mathrm{C}$. A melting curve was performed at $65^{\circ} \mathrm{C}-95^{\circ} \mathrm{C}$ with increments of $0.5^{\circ} \mathrm{C}$ for 5 seconds. Relative fold gene expression data were collected and subjected to statistical analysis.

\section{Statistical Analysis}

All data were analyzed using the General Linear Model procedure of SAS. To account for trial $(n=3)$ differences, the data were analyzed in a Randomized Complete Block Design. Means were considered significant at the 5\% level of probability.

\section{Results and Discussion}

Grazing goats screened for FEC, FAM and PCV confirmed GIN infection (data not shown). Primers designed to target benzimidazole sensitive and resistant strains successfully amplified 208 bp fragments (Figure1) of the Haemonchus contortus $\beta$ tubulin isotype-1 gene from extracted goat fecal RNA. The BLAST (Altschul, Gish, Miller, Myers, \& Lipman, 1990; Altschul et al., 1997) results verified that the amplified 208 bp fragments were $100 \%$ Haemonchus contortus $\beta$ tubulin isotype-1. Nucleotide and amino acid sequence analysis of the $208 \mathrm{bp}$ fragments verified the presence of both the wild type TTC and the TAC SNP. (Figures 2-3) and the Phe to Tyr amino acid change. Endpoint PCR analysis showed that Spanish goats had 28\% higher $(\mathrm{P}<0.05)$ amounts of both benzimidazole sensitive and resistant strains of Haemonchus contortus in stool than Myotonic goats (Figure 4). Bucks also had $25 \%$ higher $(\mathrm{P}<0.05)$ of both sensitive and resistant strains of Haemonchus contortus than Does (Figure 5). The qRT-PCR analysis allowed detection and quantification of both benzimidazole sensitive and resistant strains of Haemonchus contortus $\beta$ tubulin isotype-1 cDNA, however no significant differences in Haemonchus contortus sensitive and resistant loads $(\mathrm{P}>0.05)$ were evident between breeds and gender (Figures 6-7). Benzimidazole resistance of Haemonchus contortus has become a serious problem for small ruminant farmers worldwide (Dorny, Claerebout, Vercruysse, Jalila, \& Sani, 1993; Dorny, Claerebout, Vercruysse, Sani, \& Jalila, 1994). Therefore many tests have been developed for evaluating the benzimidazole resistance phenotype or genotype of this parasite (Alvarez-Sánchez et al., 2005; Andrews, 2000; Beech et al., 1994; Echevarria, Gennari, \& Tait, 1992; Garg \& Yadav, 2009; Geary et al., 1992; Herd, Streitel, McClure, \& Parker, 1984; Lacey \& Snowdon, 1988; Otsen et al., 2001; Roos et al., 1990; Silvestre \& Humbert, 2000). Sustainable use of anthelmintics requires regular monitoring of drug efficacy on individual small ruminant farms (Dobson, Hosking, Besier, et al., 2011; Dobson, Hosking, Jacobson, et al., 2011). In addition to the FAM, FEC and PCV standard diagnostic methods, another common phenotypic test is the egg hatch test (Hall, Campbell, \& Richardson, 1978; von Samson-Himmelstjerna, Coles, et al., 2009; Várady et al., 2007), which is based on the drug concentration required to inhibit hatching of $50 \%$ of nematode eggs. The sensitivity of such methods is relatively poor, and molecular diagnostic tests such as qRT-PCR, designed to target anthelmintic drug resistance through gene polymorphisms are usually highly sensitive (Alvarez-Sánchez et al., 2005; Barrère et al., 2011; von Samson-Himmelstjerna, Walsh, et al., 2009; Walsh, Donnan, Jackson, Skuce, \& Wolstenholme, 2007). The results of this study demonstrate that molecular quantitation of Haemonchus contortus load and detection of its resistance to benzimidazole based anthelmintics is possible. Correlations (data not shown) between standard methods of detection behaved as expected in that high FAM eye color scores were indicative of a low PCV and a high FEC. The weak relationship between molecular quantitation methods and standard methods (FEC and FAM) emphasized the difference between qualitative vs. quantitative and species specific detection methods. Although the FEC method is semi-quantitative, direct detection of Haemonchus contortus may not always be accurate since the counts are highly dependent on the size of the egg $(80-90 \mathrm{~nm})$. Studies still strive to improve the 
accuracy of the FEC method in the hopes of preserving new anthelmintics (Dobson, Hosking, Jacobson, et al., 2011; Grimshaw, Hong, \& Hunt, 1996). Even though qRT-PCR analysis could not detect a significant difference between breed and gender, benzimidazole sensitive and resistant strains of Haemonchus contortus were successfully detected and quantified in goat feces using the $\beta$ tubulin isotype- 1 gene SNP. With acknowledgement that endpoint PCR is semi-quantitative and not as reliable as qRT-PCR, this method still served as a molecular based method to specifically identify Haemonchus contortus in naturally exposed Myotonic and Spanish grazing goats.

\section{Conclusion}

These results imply that molecular detection and quantitation methods are a good way to enhance standard methods of detection and thus allow closer monitoring of the development of anthelmintic resistance in goats. However, these data do not translate into replacement of the standard methods of Haemonchus contortus detection, but demonstrate that molecular detection of Haemonchus contortus is necessary not only for definitive diagnosis and parasite load, but that SNP detection can aid in determining whether animals are infected with benzimidazole sensitive or resistant strains of Haemonchus contortus. Molecular detection can save the livestock industry billions of dollars in that it can aid pharmaceutical companies to target this GIN at the molecular level and thus improve anthelmintic drugs to treat Haemonchus contortus. The trickle down effect or impact on the small ruminant industry will be evident when farmers and producers are able to make better informed decisions on what species of goat to purchase for breeding stock and when to administer the most effective anthelmintic.

\section{References}

Altschul, S. F., Gish, W., Miller, W., Myers, E. W., \& Lipman, D. J. (1990). Basic local alignment search tool. $J$ Mol Biol, 215(3), 403-410. http://dx.doi.org/10.1016/S0022-2836(05)80360-2

Altschul, S. F., Madden, T. L., Schäffer, A. A., Zhang, J., Zhang, Z., Miller, W., \& Lipman, D. J. (1997). Gapped BLAST and PSI-BLAST: a new generation of protein database search programs. Nucleic Acids Res, 25(17), 3389-3402.

Alvarez-Sánchez, M. A., Pérez-García, J., Cruz-Rojo, M. A., \& Rojo-Vázquez, F. A. (2005). Real time PCR for the diagnosis of benzimidazole resistance in trichostrongylids of sheep. Vet Parasitol, 129(3-4), 291-298. http://dx.doi.org/10.1016/j.vetpar.2005.02.004

Andrews, S. J. (2000). The efficacy of levamisole, and a mixture of oxfendazole and levamisole, against the arrested stages of benzimidazole-resistant Haemonchus contortus and Ostertagia circumcincta in sheep. Vet Parasitol, 88(1-2), 139-146.

Anosa, V. O., \& Isoun, T. T. (1976). Serum proteins, blood and plasma volumes in experimental Trypanosoma vivax infections of sheep and goats. Trop Anim Health Prod, 8(1), 14-19. http://dx.doi.org/10.1007/BF02383360

Barrère, V., Alvarez, L., Suarez, G., Ceballos, L., Moreno, L., Lanusse, C., \& Prichard, R. K. (2011). Relationship between increased albendazole systemic exposure and changes in single nucleotide polymorphisms on the $\beta$-tubulin isotype 1 encoding gene in Haemonchus contortus. Vet Parasitol. http://dx.doi.org/10.1016/j.vetpar.2011.11.068

Barton, N. J., Trainor, B. L., Urie, J. S., Atkins, J. W., Pyman, M. F., \& Wolstencroft, I. R. (1985). Anthelmintic resistance in nematode parasites of goats. Aust Vet J, 62(7), 224-227. http://dx.doi.org/10.1111/j.1751-0813.1985.tb07318.x

Beech, R. N., Prichard, R. K., \& Scott, M. E. (1994). Genetic variability of the beta-tubulin genes in benzimidazole-susceptible and -resistant strains of Haemonchus contortus. Genetics, 138(1), 103-110.

Bjørn, H., Monrad, J., Kassuku, A. A., \& Nansen, P. (1990). Resistance to benzimidazoles in Haemonchus contortus of sheep in Tanzania. Acta Trop, 48(1), 59-67. http://dx.doi.org/10.1016/0001-706X(90)90065-8

Borgsteede, F. H., Pekelder, J. J., \& Dercksen, D. P. (1996). Anthelmintic resistant nematodes in goats in The Netherlands. Vet Parasitol, 65(1-2), 83-87. http://dx.doi.org/10.1016/0304-4017(95)00931-0

Cringoli, G., Rinaldi, L., Veneziano, V., Capelli, G., \& Scala, A. (2004). The influence of flotation solution, sample dilution and the choice of McMaster slide area (volume) on the reliability of the McMaster technique in estimating the faecal egg counts of gastrointestinal strongyles and Dicrocoelium dendriticum in sheep. Vet Parasitol, 123(1-2), 121-131. http://dx.doi.org/10.1016/j.vetpar.2004.05.021

Dobson, R. J., Hosking, B. C., Besier, R. B., Love, S., Larsen, J. W., Rolfe, P. F., \& Bailey, J. N. (2011). Minimising the development of anthelmintic resistance, and optimising the use of the novel anthelmintic 
monepantel, for the sustainable control of nematode parasites in Australian sheep grazing systems. Aust Vet $J$, 89(5), 160-166. http://dx.doi.org/10.1111/j.1751-0813.2011.00703.x

Dobson, R. J., Hosking, B. C., Jacobson, C. L., Cotter, J. L., Besier, R. B., Stein, P. A., \& Reid, S. A. (2011). Preserving new anthelmintics: A simple method for estimating faecal egg count reduction test (FECRT) confidence limits when efficacy and/or nematode aggregation is high. Vet Parasitol. http://dx.doi.org/10.1016/j.vetpar.2011.11.049

Dorny, P., Claerebout, E., Vercruysse, J., Jalila, A., \& Sani, R. (1993). Benzimidazole resistance of Haemonchus contortus in goats in Malaysia. Vet Rec, 133(17), 423-424. http://dx.doi.org/10.1136/vr.133.17.423

Dorny, P., Claerebout, E., Vercruysse, J., Sani, R., \& Jalila, A. (1994). Anthelmintic resistance in goats in peninsular Malaysia. Vet Parasitol, 55(4), 327-342. http://dx.doi.org/10.1016/0304-4017(94)90073-6

Echevarria, F. A., Gennari, S. M., \& Tait, A. (1992). Isoenzyme analysis of Haemonchus contortus resistant or susceptible to ivermectin. Vet Parasitol, 44(1-2), 87-95. http://dx.doi.org/10.1016/0304-4017(92)90146-Z

Ejlertsen, M., Githigia, S. M., Otieno, R. O., \& Thamsborg, S. M. (2006). Accuracy of an anaemia scoring chart applied on goats in sub-humid Kenya and its potential for control of Haemonchus contortus infections. Vet Parasitol, 141(3-4), 291-301. http://dx.doi.org/10.1016/j.vetpar.2006.05.020

Garg, R., \& Yadav, C. L. (2009). Genotyping of benzimidazole susceptible and resistant alleles in different populations of Haemonchus contortus from Himalayan and sub-Himalayan regions of North-West India. Trop Anim Health Prod, 41(7), 1127-1131. http://dx.doi.org/10.1007/s11250-008-9292-5

Gauly, M., Schackert, M., \& Erhardt, G. (2004). Use of FAMACHA Scoring System as a diagnostic aid for the registration of distinguishing marks in the breeding program for lambs exposed to an experimental Haemonchus contortus infection. Dtsch Tierarztl Wochenschr, 111(11), 430-433.

Gauthier, E. R., Madison, S. D., \& Michel, R. N. (1997). Rapid RNA isolation without the use of commercial kits: application to small tissue samples. Pflugers Arch, 433(5), 664-668. http://dx.doi.org/10.1007/s004240050328

Geary, T. G., Nulf, S. C., Favreau, M. A., Tang, L., Prichard, R. K., Hatzenbuhler, N. T., .. . Klein, R. D. (1992). Three beta-tubulin cDNAs from the parasitic nematode Haemonchus contortus. Mol Biochem Parasitol, 50(2), 295-306. http://dx.doi.org/10.1016/0166-6851(92)90227-B

Ghisi, M., Kaminsky, R., \& Mäser, P. (2007). Phenotyping and genotyping of Haemonchus contortus i solates reveals a new putative candidate mutation for benzimidazole resistance in nematodes. Vet Parasitol, 144(3-4), 313-320. http://dx.doi.org/10.1016/j.vetpar.2006.10.003

Gilleard, J. S. (2006). Understanding anthelmintic resistance: the need for genomics and genetics. Int J Parasitol, 36(12), 1227-1239. http://dx.doi.org/10.1016/j.ijpara.2006.06.010

Grimshaw, W. T., Hong, C., \& Hunt, K. R. (1996). Potential for misinterpretation of the faecal egg count reduction test for levamisole resistance in gastrointestinal nematodes of sheep. Vet Parasitol, 62(3-4), $267-273$. http://dx.doi.org/10.1016/0304-4017(95)00874-8

Hall, C. A., Campbell, N. J., \& Richardson, N. J. (1978). Levels of benzimidazole resistance in Haemonchus contortus and Trichostrongylus colubriformis recorded from an egg hatch test procedure. Res Vet Sci, 25(3), 360-363.

Herd, R. P., Streitel, R. H., McClure, K. E., \& Parker, C. F. (1984). Control of hypobiotic and benzimidazole-resistant nematodes of sheep. J Am Vet Med Assoc, 184(6), 726-730.

Howell, S. B., Burke, J. M., Miller, J. E., Terrill, T. H., Valencia, E., Williams, M. J., . . Kaplan, R. M. (2008). Prevalence of anthelmintic resistance on sheep and goat farms in the southeastern United States. J Am Vet Med Assoc, 233(12), 1913-1919. http://dx.doi.org/10.2460/javma.233.12.1913

Höglund, J., Gustafsson, K., Ljungström, B. L., Engström, A., Donnan, A., \& Skuce, P. (2009). Anthelmintic resistance in Swedish sheep flocks based on a comparison of the results from the faecal egg count reduction test and resistant allele frequencies of the beta-tubulin gene. Vet Parasitol, 161(1-2), 60-68. http://dx.doi.org/10.1016/j.vetpar.2008.12.001

Kaplan, R. M., Burke, J. M., Terrill, T. H., Miller, J. E., Getz, W. R., Mobini, S., . . . Vatta, A. F. (2004). Validation of the FAMACHA eye color chart for detecting clinical anemia in sheep and goats on farms in the southern United States. Vet Parasitol, 123(1-2), 105-120. http://dx.doi.org/10.1016/j.vetpar.2004.06.005 
Kelly, J. D., Whitlock, H. V., Thompson, H. G., Hall, C. A., Martin, I. C., \& Le Jambre, L. F. (1978). Physiological characteristics of free-living and parasitic stages of strains of Haemonchus contortus, susceptible or resistant to benzimidazole anthelmintics. Res Vet Sci, 25(3), 376-385.

Koopmann, R., Holst, C., \& Epe, C. (2006). Experiences with the FAMACHA-Eye-Colour-Chart for identifying sheep and goats for targeted anthelmintic treatment. Berl Munch Tierarztl Wochenschr, 119(9-10), 436-442.

Kwa, M. S., Kooyman, F. N., Boersema, J. H., \& Roos, M. H. (1993). Effect of selection for benzimidazole resistance in Haemonchus contortus on beta-tubulin isotype 1 and isotype 2 genes. Biochem Biophys Res Commun, 191(2), 413-419. http://dx.doi.org/10.1006/bbrc.1993.1233

Kwa, M. S., Veenstra, J. G., \& Roos, M. H. (1993). Molecular characterisation of beta-tubulin genes present in benzimidazole-resistant populations of Haemonchus contortus. Mol Biochem Parasitol, 60(1), 133-143.

Kwa, M. S., Veenstra, J. G., \& Roos, M. H. (1994). Benzimidazole resistance in Haemonchus contortus is correlated with a conserved mutation at amino acid 200 in beta-tubulin isotype 1. Mol Biochem Parasitol, 63(2), 299-303. http://dx.doi.org/10.1016/0166-6851(94)90066-3

Lacey, E., \& Snowdon, K. L. (1988). A routine diagnostic assay for the detection of benzimidazole resistance in parasitic nematodes using tritiated benzimidazole carbamates. Vet Parasitol, 27(3-4), 309-324. http://dx.doi.org/10.1016/0304-4017(88)90045-3

Levecke, B., Behnke, J. M., Ajjampur, S. S., Albonico, M., Ame, S. M., Charlier, J., . . Vercruysse, J. (2011). A comparison of the sensitivity and fecal egg counts of the McMaster egg counting and Kato-Katz thick smear methods for soil-transmitted helminths. PLoS Negl Trop Dis, 5(6), e1201. http://dx.doi.org/10.1371/journal.pntd.0001201

Lubega, G. W., Klein, R. D., Geary, T. G., \& Prichard, R. K. (1994). Haemonchus contortus: the role of two beta-tubulin gene subfamilies in the resistance to benzimidazole anthelmintics. Biochem Pharmacol, 47(9), 1705-1715.

Moake, J. L., \& Schultz, D. R. (1975). Hemolytic anemia associated with multiple autoantibodies and low serum complement. Am J Med, 58(3), 431-437. http://dx.doi.org/10.1016/0002-9343(75)90610-5

Nicholson, S. S. (2011). Southeastern plants toxic to ruminants. Vet Clin North Am Food Anim Pract, 27(2), 447-458. http://dx.doi.org/10.1016/j.cvfa.2011.02.008

Otsen, M., Hoekstra, R., Plas, M. E., Buntjer, J. B., Lenstra, J. A., \& Roos, M. H. (2001). Amplified fragment length polymorphism analysis of genetic diversity of Haemonchus contortus during selection for drug resistance. Int J Parasitol, 31(10), 1138-1143.

Otsen, M., Plas, M. E., Lenstra, J. A., Roos, M. H., \& Hoekstra, R. (2000). Microsatellite diversity of isolates of the parasitic nematode Haemonchus contortus. Mol Biochem Parasitol, 110(1), 69-77.

Prichard, R. (1994). Anthelmintic resistance. Vet Parasitol, 54(1-3), 259-268.

Rahman, W. A. (1994). Resistance to benzimidazole anthelmintics by Haemonchus contortus in goats in peninsular Malaysia. Vet Parasitol, 55(1-2), 155-157.

Reynecke, D. P., van Wyk, J. A., Gummow, B., Dorny, P., \& Boomker, J. (2011). Validation of the FAMACHAC eye colour chart using sensitivity/specificity analysis on two South African sheep farms. Vet Parasitol, 177(3-4), 203-211. http://dx.doi.org/10.1016/j.vetpar.2009.08.023

Rinaldi, L., Coles, G. C., Maurelli, M. P., Musella, V., \& Cringoli, G. (2011). Calibration and diagnostic accuracy of simple flotation, McMaster and FLOTAC for parasite egg counts in sheep. Vet Parasitol, 177(3-4), 345-352. http://dx.doi.org/10.1016/j.vetpar.2010.12.010

Roos, M. H., Boersema, J. H., Borgsteede, F. H., Cornelissen, J., Taylor, M., \& Ruitenberg, E. J. (1990). Molecular analysis of selection for benzimidazole resistance in the sheep parasite Haemonchus contortus. Mol Biochem Parasitol, 43(1), 77-88. http://dx.doi.org/10.1016/0166-6851(90)90132-6

Rufener, L., Kaminsky, R., \& Mäser, P. (2009). In vitro selection of Haemonchus contortus for benzimidazole resistance reveals a mutation at amino acid 198 of beta-tubulin. Mol Biochem Parasitol, 168(1), 120-122. http://dx.doi.org/10.1016/j.molbiopara.2009.07.002

Silverman, P. H., \& Campbell, J. A. (1959). Studies on parasitic worms of sheep in Scotland. I. Embryonic and larval development of Haemonchus contortus at constant conditions. Parasitology, 49(1-2), 23-38. http://dx.doi.org/10.1017/S0031182000026688 
Silvestre, A., \& Humbert, J. F. (2000). A molecular tool for species identification and benzimidazole resistance diagnosis in larval communities of small ruminant parasites. Exp Parasitol, 95(4), 271-276. http://dx.doi.org/10.1006/expr.2000.4542

Silvestre, A., \& Humbert, J. F. (2002). Diversity of benzimidazole-resistance alleles in populations of small ruminant parasites. Int J Parasitol, 32(7), 921-928.

Strumia, M. M., Sample, A. B., \& Hart, E. D. (1954). An improved micro hematocrit method. Am J Clin Pathol, 24(9), 1016-1024.

Strumia, M. M., Strumia, P. V., \& Dugan, A. (1968). Significance of measurement of plasma volume and of indirect estimation of red cell volume. Transfusion, 8(4), 197-209.

Tiwari, J., Kumar, S., Kolte, A. P., Swarnkar, C. P., Singh, D., \& Pathak, K. M. (2006). Detection of benzimidazole resistance in Haemonchus contortus using RFLP-PCR technique. Vet Parasitol, 138(3-4), 301-307. http://dx.doi.org/10.1016/j.vetpar.2006.02.003

von Samson-Himmelstjerna, G., Coles, G. C., Jackson, F., Bauer, C., Borgsteede, F., Cirak, V. Y., . . Wirtherle, N. (2009). Standardization of the egg hatch test for the detection of benzimidazole resistance in parasitic nematodes. Parasitol Res, 105(3), 825-834. http://dx.doi.org/10.1007/s00436-009-1466-1

von Samson-Himmelstjerna, G., Walsh, T. K., Donnan, A. A., Carrière, S., Jackson, F., Skuce, P. J., . . . Wolstenholme, A. J. (2009). Molecular detection of benzimidazole resistance in Haemonchus contortus using $\begin{array}{lllll}\text { real-time } & \mathrm{PCR} \text { and } & \text { 349-358. }\end{array}$ http://dx.doi.org/10.1017/S003118200800543X

Várady, M., Cudeková, P., \& Corba, J. (2007). In vitro detection of benzimidazole resistance in Haemonchus contortus: egg hatch test versus larval development test. Vet Parasitol, 149(1-2), 104-110. http://dx.doi.org/10.1016/j.vetpar.2007.07.011

Walsh, T. K., Donnan, A. A., Jackson, F., Skuce, P., \& Wolstenholme, A. J. (2007). Detection and measurement of benzimidazole resistance alleles in Haemonchus contortus using real-time PCR with locked nucleic acid Taqman probes. Vet Parasitol, 144(3-4), 304-312. http://dx.doi.org/ 10.1016/j.vetpar.2006.10.014

Table 1. Primers and Target Regions used for Detection and Quantitation of Haemonchus contortus benzimidazole sensitive and resistant $\beta$ tubulin isotype-1 gene SNPs from goat stool

\begin{tabular}{lllll}
\hline $\begin{array}{l}\text { Accession } \\
\text { No. }\end{array}$ & $\begin{array}{l}\text { Primer } \\
\text { name }\end{array}$ & Primer sequence & $\begin{array}{l}\text { Target } \\
\text { Region }\end{array}$ & $\begin{array}{l}\text { Fragment } \\
\text { Length }\end{array}$ \\
\hline GQ910909 & GQForward & 5'-ACCCTTTCCGTCCATCAATTGG-3' & $239-260$ & 239 \\
& GQReverse & 5'-GAATCGGAGGCAGGTCGTGACT-3' & $\begin{array}{l}\text { Complement } \\
(456-477)\end{array}$ \\
& & 5'-ACCGATGAAACATTCTGTATTGACAACGAA-3' & $270-477$ & 208 \\
& Hc & 5ensitive F & & \\
& Hc & 5'-ACCGATGAAACATACTGTATTGACAACGAA-3' & $270-477$ & 208 \\
& resistant F & & & \\
\hline
\end{tabular}




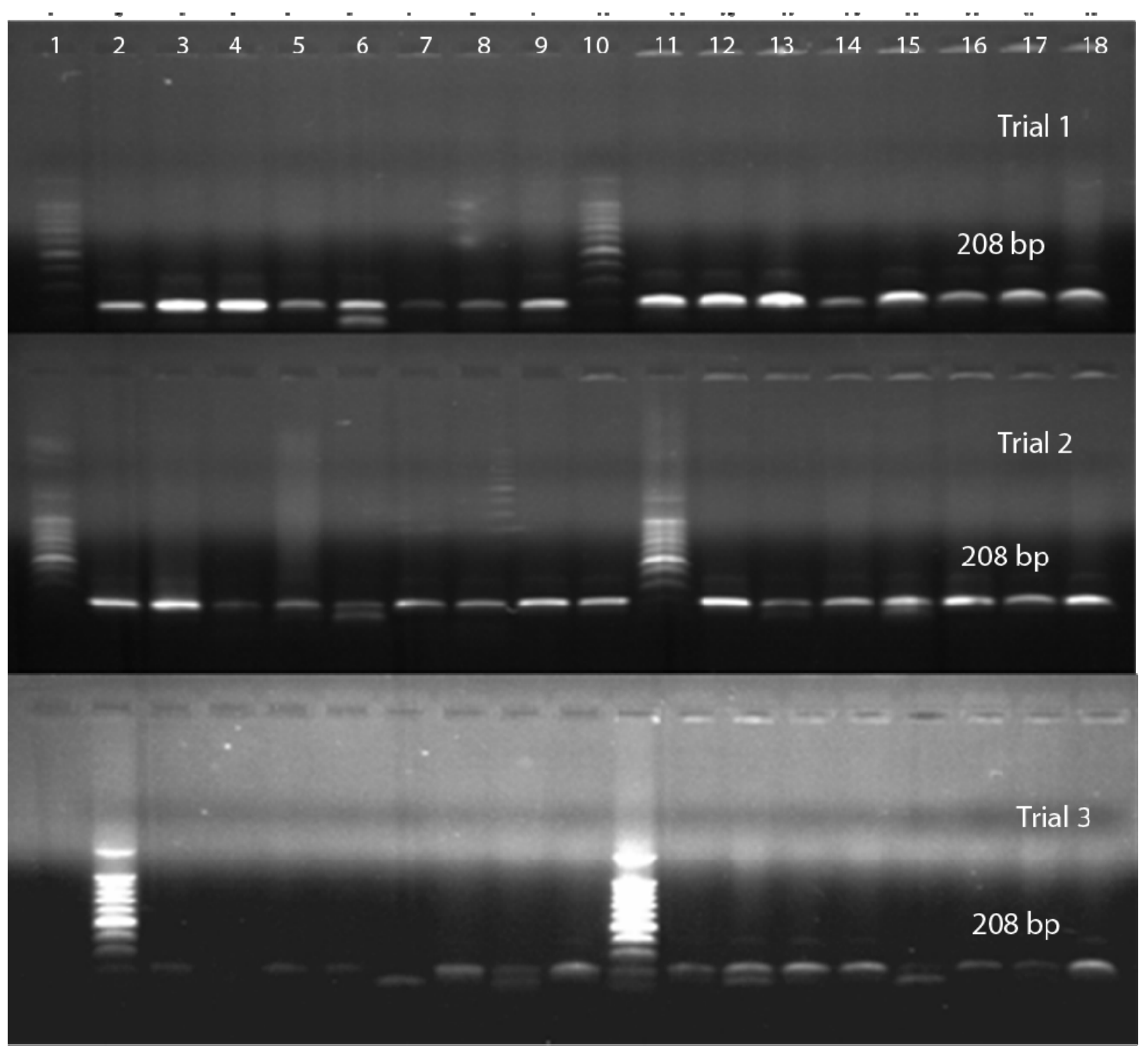

Figure 1. Gel Electrophoresis of Haemonchus contortus benzimidazole sensitive and resistant $\beta$ tubulin isotype-1 gene SNPs from goat stool. Lanes 1and 10= MW marker (100 bp), Lanes 2-9=Haemonchus contortus benzimidazole sensitive strains, Lanes 11-18 = Haemonchus contortus benzimidazole resistant strains 


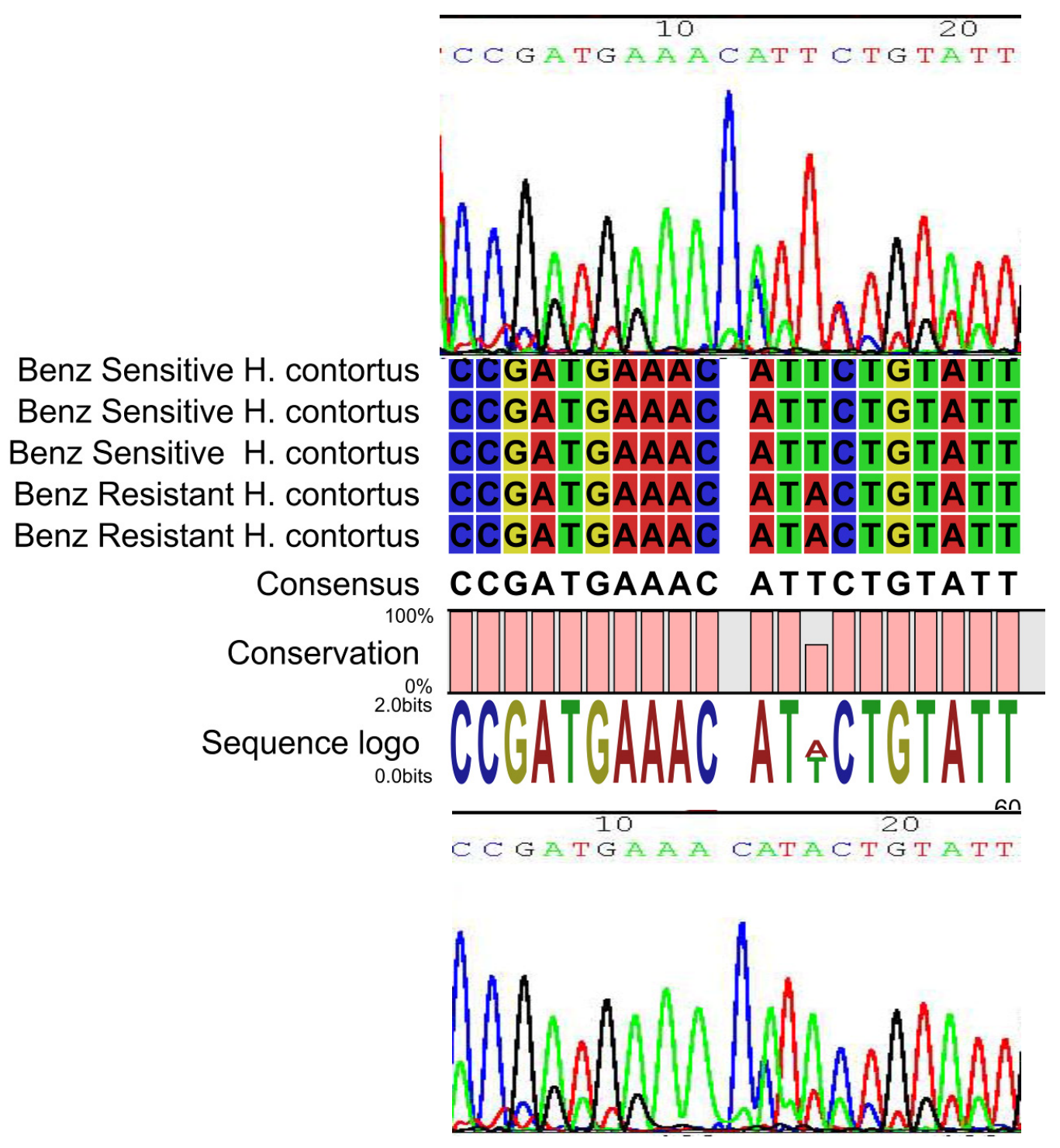

Figure 2. Nucleotide sequence alignment of the $\beta$ tubulin isotype-1 gene SNP of Haemonchus contortus benzimidazole sensitive and resistant strains isolated from goat stool

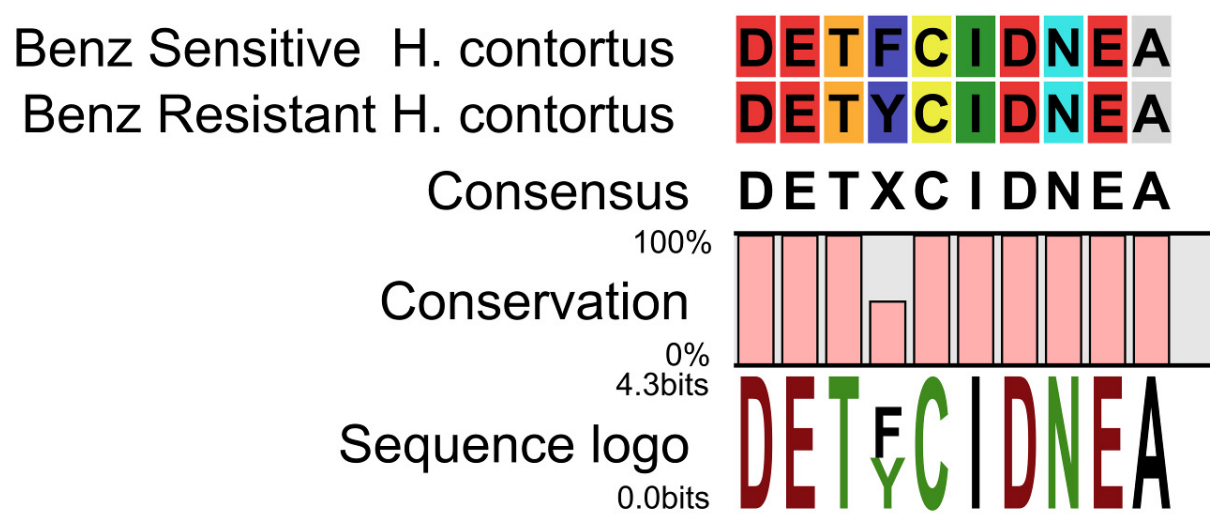

Figure 3. Amino Acid translation of Haemonchus contortus $\beta$ tubulin isotype-1 gene SNP of Haemonchus contortus isolated from goat stool 


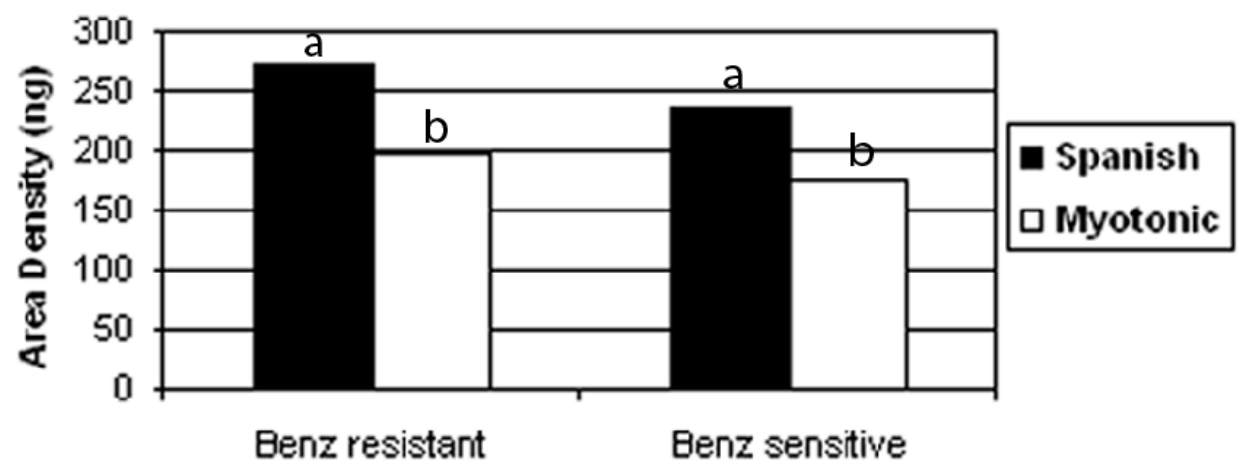

means with different letters differ $\mathrm{P}<0.05$

Figure 4. Haemonchus contortus benzimidazole sensitive and resistant strains in goats relative to breed using EndPoint PCR analysis

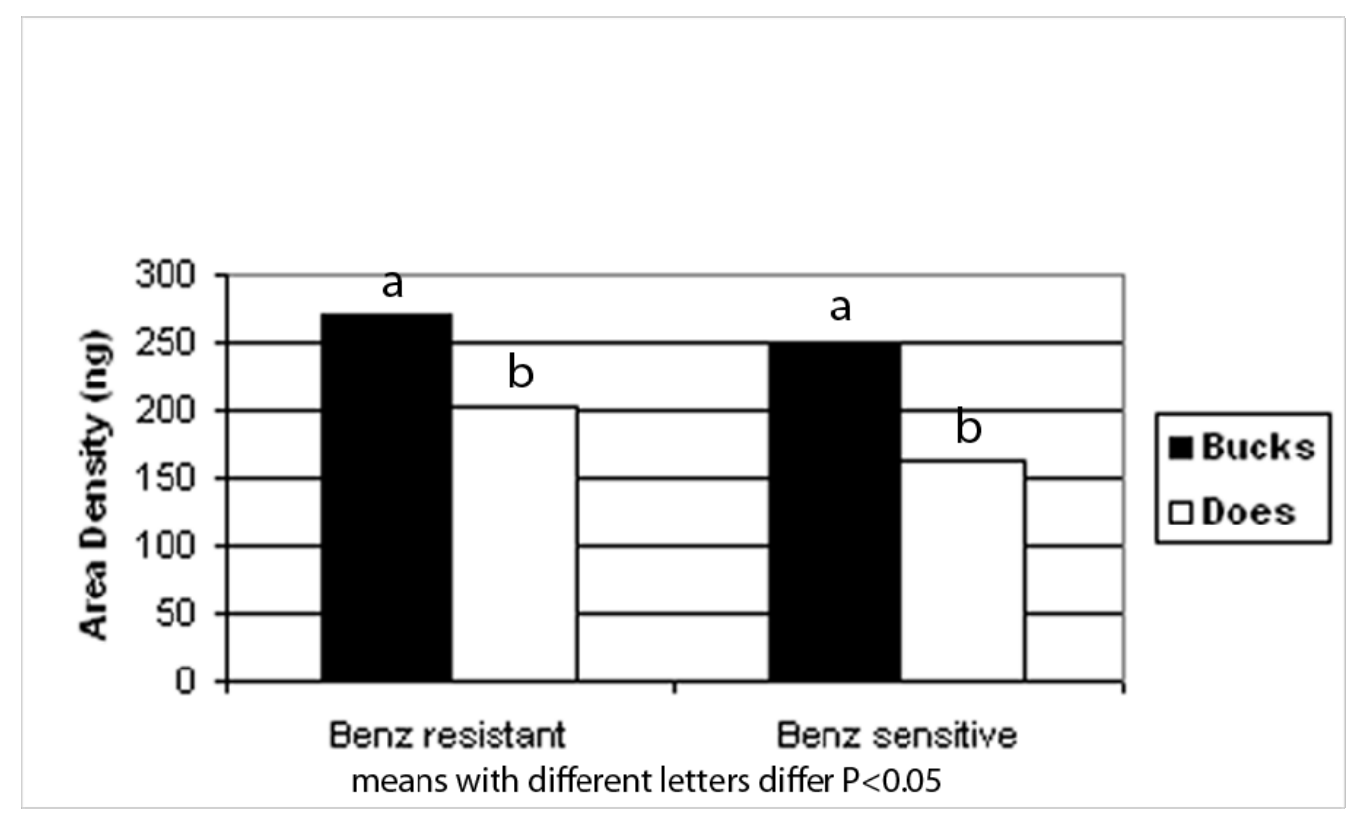

Figure 5. Haemonchus contortus benzimidazole sensitive and resistant strains in goats relative to gender using EndPoint PCR analysis 


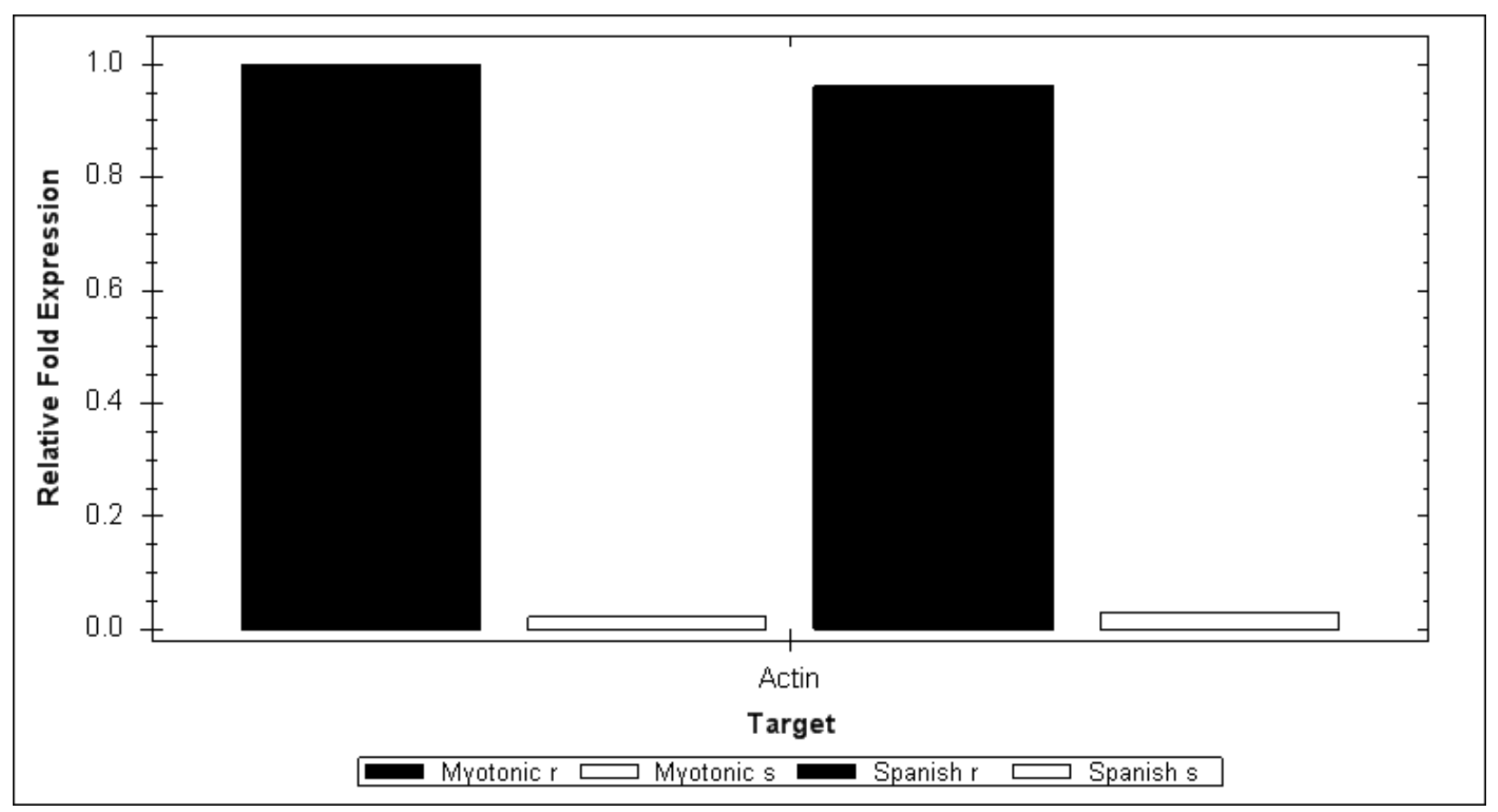

Figure 6. Haemonchus contortus benzimidazole sensitive and resistant strains in goats relative to breed using Real Time PCR analysis

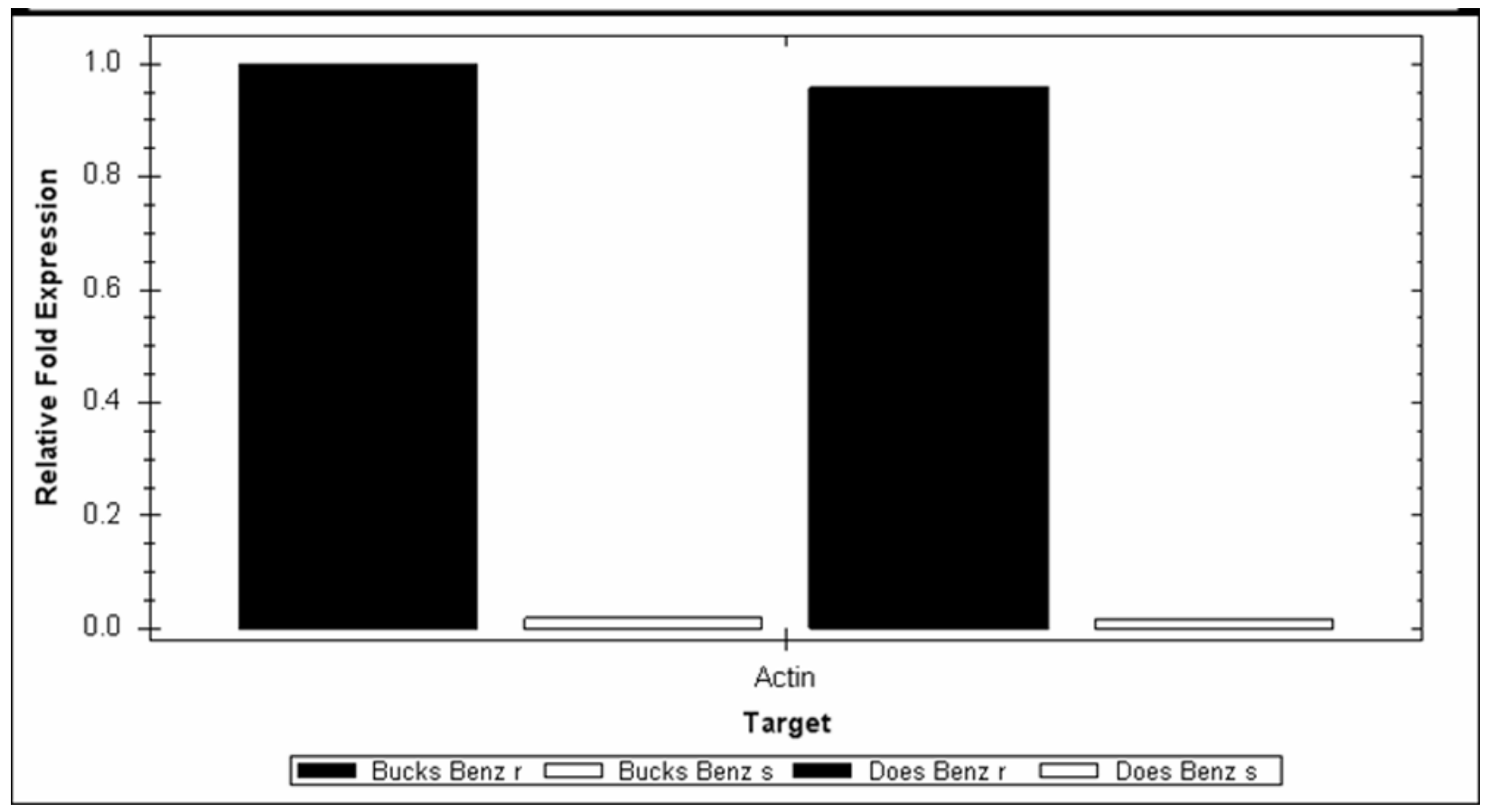

Figure 7. Haemonchus contortus benzimidazole sensitive and resistant strains in goats relative to gender using Real Time PCR analysis 